\title{
Effects of Cold Eddy on Phytoplankton Production and Assemblages in Luzon Strait Bordering the South China Sea
}

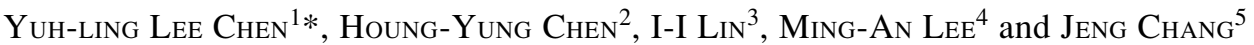 \\ ${ }^{I}$ Department of Marine Biotechnology and Resources, National Sun Yat-sen University, \\ Kaohsiung, Taiwan \\ ${ }^{2}$ Institute of Marine Biology, National Sun Yat-sen University, Kaohsiung, Taiwan \\ ${ }^{3}$ Department of Atmospheric Sciences, National Taiwan University, Taipei, Taiwan \\ ${ }^{4}$ Department of Environmental Biology and Fishery Science, National Taiwan Ocean University, \\ Keelung, Taiwan \\ ${ }^{5}$ Institute of Marine Biology, National Taiwan Ocean University, Keelung, Taiwan
}

(Received 19 September 2006; in revised form 9 March 2007; accepted 12 March 2007)

The biochemical effects of a cold-core eddy that was shed from the Kuroshio Current at the Luzon Strait bordering the South China Sea (SCS) were studied in late spring, a relatively unproductive season in the SCS. The extent of the eddy was determined by time-series images of SeaWiFS ocean color, AVHRR sea surface temperature, and TOPEX/Jason-1 sea surface height anomaly. Nutrient budgets, nitrate-based new production, primary production, and phytoplankton assemblages were compared between the eddy and its surrounding Kuroshio and SCS waters. The enhanced productivity in the eddy was comparable to wintertime productivity in the SCS basin, which is supported by upwelled subsurface nitrate under the prevailing Northeastern Monsoon. There were more Synechococcus, pico-eucaryotes, and diatoms, but less Trichodesmium in the surface water inside the eddy than outside. Prochlorococcus and Richelia intracellularis showed no spatial differences. Water column-integrated primary production (IPP) inside the eddy was 2-3 times that outside the eddy in the SCS (1.09 vs. $\left.0.59 \mathrm{~g} \mathrm{C} \mathrm{m}^{-2} \mathrm{~d}^{-1}\right)$, as was nitrate-based new production (INP) (0.67 vs. $0.25 \mathrm{~g} \mathrm{C}$ $\left.\mathrm{m}^{-2} \mathrm{~d}^{-1}\right)$. INP in the eddy was 6 times that in the Kuroshio $\left(0.12 \mathrm{~g} \mathrm{C} \mathrm{m}^{-2} \mathrm{~d}^{-1}\right)$. IPP and INP in the eddy were higher than the maximum production values ever measured in the SCS basin. Surface chlorophyll $a$ concentration $\left(0.40 \mathrm{mg} \mathrm{m}^{-3}\right)$ in the eddy equaled the maximum concentration registered for the SCS basin and was higher than the wintertime average $\left(0.29 \pm 0.04 \mathrm{mg} \mathrm{m}^{-3}\right)$. INP was 3.5 times as great and IPP was doubled in the eddy compared to the wintertime SCS basin. As cold core eddies form intermittently all year round as the Kuroshio invades the SCS, their effects on phytoplankton productivity and assemblages are likely to have important influences on the biogeochemical cycle of the region.
Keywords:

- Phytoplankton assemblage, - primary production,

- new production,

- eddy,

- Luzon Strait,

- Kuroshio,

- South China Sea.

\section{Introduction}

The South China Sea (SCS), with a broad shelf and a deep basin, is the largest marginal sea in the western tropical Pacific Ocean (Fig. 1). The Luzon Strait, located at the northeastern rim of the basin, separates Taiwan and the Philippine Islands. With a sill depth of about $2400 \mathrm{~m}$, the Luzon Strait allows effective water exchange between

\footnotetext{
* Corresponding author. E-mail: yllee@mail.nsysu.edu.tw Copyright $\odot$ The Oceanographic Society of Japan/TERRAPUB/Springer
}

the SCS and the Western Pacific Ocean. The Kuroshio Current enters the northern SCS through the Luzon Strait. Studies conducted in the northern SCS bordering the Luzon Strait report occurrences of intermittent eddies driven by the westward flow of the Kuroshio Current ( $\mathrm{Li}$ et al., 1998; Chu and Fan, 2001; Metzger and Hurlburt, 2001).

The SCS accommodates a multi-eddy structure (Chu et al., 1998). At its northeastern rim, cold-core cyclonic (Chu et al., 1998) and warm-core anticyclonic (Li et al., 1998) eddies form in the Luzon Strait off northwestern 


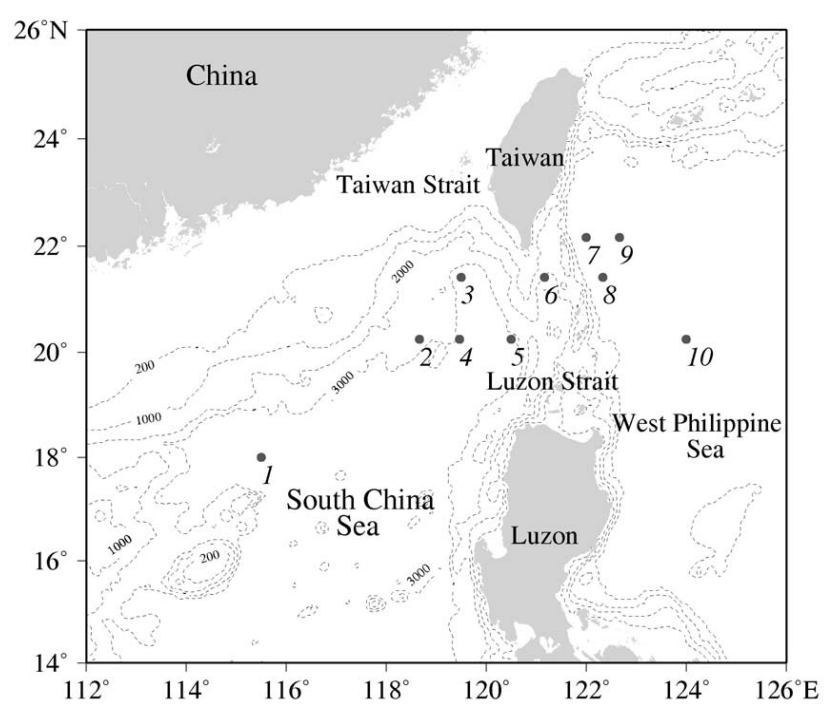

Fig. 1. Locations of sampling stations in the northern South China Sea (SCS) and the Kuroshio. Station 5 was inside a cold-core eddy. Stations at west side and east side of $121^{\circ} \mathrm{E}$ were grouped as SCS stations and Kuroshio stations, respectively. Station 1 was the SEATS (South East Asian Time-series Study) station.

Luzon Island. The formation of these eddies seems to be related to how the Kuroshio bends during its intrusion and the circulation patterns of the northeastern SCS. Cyclonic eddies form when the circulation bifurcates, while anticyclonic eddies form when the circulation adopts a loop pattern (Metzger and Hurlburt, 1996). Jia and Liu (2004), however, suggested that anticyclones could form as the Kuroshio intrudes into the SCS through the southern Luzon Strait, and exits subsequently from the SCS to rejoin the Kuroshio through the northern Luzon Strait. Shedding of these anticyclonic eddies occurs when cyclonic eddies form in the south of the Kuroshio bend (Jia et al., 2005). These cyclonic eddies occur off northern Luzon Island and grow with the extension of the Kuroshio bend. Several previous studies that are relevant to the Luzon Strait eddies cover a range of topics, including mechanisms of eddy formation based on TOPEX/ POSEIDON and ERS satellite altimeter data (Wu et al., 1999; Li et al., 2002; Jia and Liu, 2004), hydrographic surveys based on temperature and salinity patterns (e.g. Li et al., 1998; Chu and Fan, 2001), and numerical model simulations (Metzger and Hurlburt, 2001; Chern and Wang, 2003; Jia et al., 2005).

Eddies, especially cyclonic eddies, contribute significantly to regional biogeochemical budgets (McGillicuddy et al., 1998, 2003; Siegel et al., 1999). At higher latitudes in the Sargasso Sea or BATS (Bermuda Atlantic Time Series Study) (McGillicuddy and Robinson,
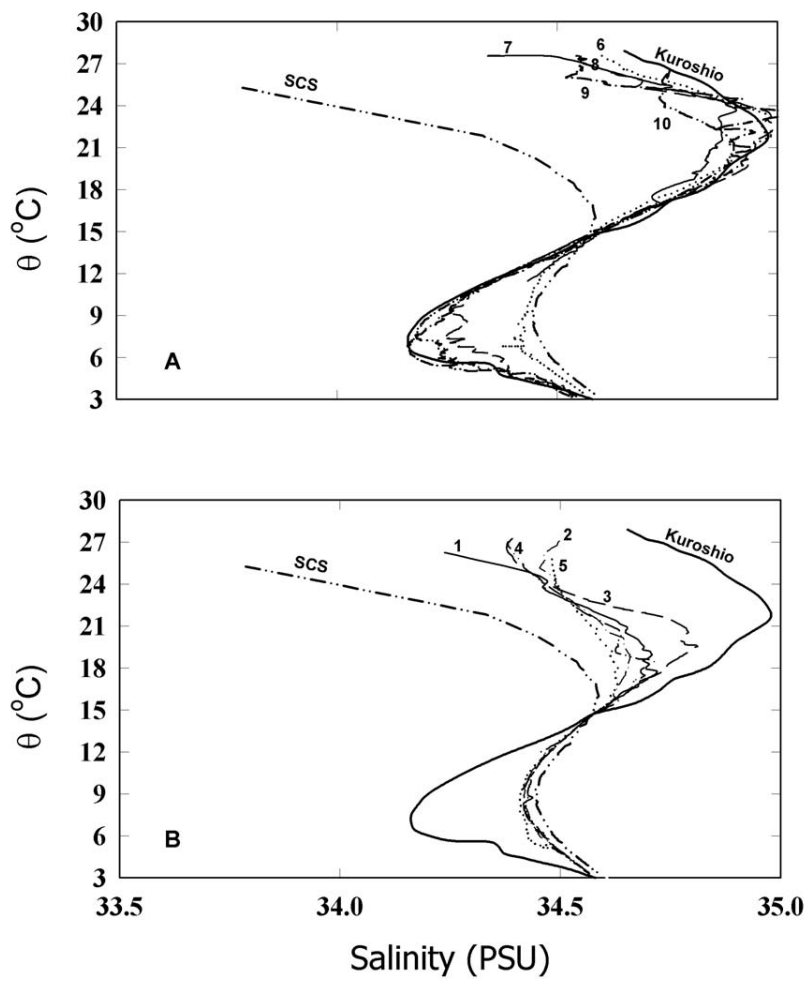

Fig. 2. Temperature versus salinity $(\theta / \mathrm{S})$ plots for (A) five Kuroshio stations (St. 6-10), and (B) the cold-core eddy station (St. 5) and four South China Sea stations (St. 1-4) during April-May of 2005. Typical South China Sea (SCS) and Kuroshio $\theta / \mathrm{S}$ curves are based on measurements made by Chen and Huang (1996).

1997; McGillicuddy et al., 1998, 1999; McNeil et al., 1999; Siegel et al., 1999; Sweeney et al., 2003) and in the North Pacific subtropical gyre near Hawaii (Allen $e t$ al., 1996; Vaillancourt et al., 2003), nutrient concentrations, chlorophyll $a$ concentrations, photosynthetic rates, and new production inside cyclonic eddies were found to be greatly enhanced. The biogeochemical effects of coldcore eddies at lower latitudes, such as in the SCS, where surface water tends to be oligotrophic, are poorly understood.

Phytoplankton growth in the SCS is limited by nitrogen (Chen et al., 2004). Nitrate-based new production and primary production in its basin show a distinct seasonality, being highest in the winter (Chen, 2005; Chen and Chen, 2006). The wintertime productivity is supported by upwelled subsurface nitrate driven by the prevailing cold Northwest Monsoon. Phytoplankton assemblages change successively with seasonally fluctuating productivity. While diatoms and coccolithophores are more prolific in winter than in summer (Chen, 2005), 
Table 1. Water properties including surface water temperature, salinity, $\mathrm{NO}_{3}+\mathrm{NO}_{2}$ concentration, phosphate concentration (soluble reactive phosphorus, SRP), silicate concentration $\left(\mathrm{SiO}_{2}\right)$, chlorophyll $a$ concentration (Chl), primary production (PP), nitrate-based new production (NP), ratio of primary production to nitrate-based new production (PP/NP), euphotic depth (Zeu), depth of mixed layer (MLD), nitracline depth (defined as depth with $0.1 \mu \mathrm{M} \mathrm{NO}_{3}+\mathrm{NO}_{2}$ ), as well as water column integrated $\mathrm{NO}_{3}+\mathrm{NO}_{2}$ from surface to the euphotic depth $\left(\mathrm{INO}_{3}+\mathrm{NO}_{2}\right)$ and water column integrated primary production (IPP), nitrate-based new production (INP) and the ratio of IPP to INP (IPP/INP) at the cold-core eddy station (St. 5) and the surrounding South China Sea (SCS) stations (St. 1-4) and Kuroshio stations (St. 6-10) during April-May of 2005.

\begin{tabular}{|c|c|c|c|c|}
\hline Variables & Eddy station & $\begin{array}{l}\text { SCS stations } \\
\quad(n=4)\end{array}$ & $\begin{array}{l}\text { Kuroshio stations } \\
\qquad(n=5)\end{array}$ & $\begin{array}{l}\text { Overall mean } \\
\quad(n=10)\end{array}$ \\
\hline \multicolumn{5}{|l|}{ Surface water } \\
\hline Temperature $\left({ }^{\circ} \mathrm{C}\right)$ & 25.8 & $26.9 \pm 0.4$ & $27.5 \pm 0.2$ & $27.1 \pm 0.2$ \\
\hline Salinity & 34.49 & $34.36 \pm 0.05$ & $34.59 \pm 0.05$ & $34.49 \pm 0.05$ \\
\hline $\mathrm{NO}_{3}+\mathrm{NO}_{2}(\mathrm{nM})$ & 107 & $14 \pm 1$ & $21 \pm 5$ & $27 \pm 9$ \\
\hline $\mathrm{SRP}(\mathrm{nM})$ & 70 & $21 \pm 3$ & $19 \pm 2$ & $25 \pm 5$ \\
\hline $\mathrm{SiO}_{2}(\mu \mathrm{M})$ & 2.43 & $1.89 \pm 0.06$ & $0.98 \pm 0.36$ & $1.49 \pm 0.18$ \\
\hline $\mathrm{Chl}\left(\mathrm{mg} \mathrm{m}^{-3}\right)$ & 0.40 & $0.13 \pm 0.01$ & $0.09 \pm 0.02$ & $0.14 \pm 0.03$ \\
\hline 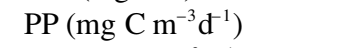 & 41.4 & $13.0 \pm 0.9$ & $9.5 \pm 1.3$ & $15.6 \pm 4.4$ \\
\hline $\mathrm{NP}\left(\mathrm{mg} \mathrm{C} \mathrm{m}^{-3} \mathrm{~d}^{-1}\right)$ & 26.3 & $2.0 \pm 0.3$ & $1.7 \pm 0.7$ & $5.4 \pm 3.5$ \\
\hline $\mathrm{NP} / \mathrm{PP}$ & 0.64 & $0.16 \pm 0.02$ & $0.18 \pm 0.07$ & $0.23 \pm 0.07$ \\
\hline \multicolumn{5}{|l|}{ Water column } \\
\hline Zeu (m) & 62 & $96 \pm 6$ & $131 \pm 12$ & $106 \pm 11$ \\
\hline $\operatorname{MLD}(\mathrm{m})$ & 26 & $46 \pm 15$ & $98 \pm 28$ & $70 \pm 17$ \\
\hline Nitracline depth (m) & 0 & $48 \pm 6$ & $73 \pm 8$ & $56 \pm 8$ \\
\hline $\mathrm{INO}_{3}+\mathrm{NO}_{2}\left(\mathrm{~m}\right.$ mole $\left.\mathrm{m}^{-2}\right)$ & 526 & $183 \pm 25$ & $16 \pm 8$ & $134 \pm 52$ \\
\hline $\operatorname{IPP}\left(\mathrm{g} \mathrm{C} \mathrm{m}^{-2} \mathrm{~d}^{-1}\right)$ & 1.09 & $0.59 \pm 0.06$ & $0.54 \pm 0.19$ & $0.64 \pm 0.11$ \\
\hline $\operatorname{INP}\left(\mathrm{g} \mathrm{C} \mathrm{m}^{-2} \mathrm{~d}^{-1}\right)$ & 0.67 & $0.25 \pm 0.12$ & $0.12 \pm 0.03$ & $0.25 \pm 0.09$ \\
\hline INP/IPP & 0.62 & $0.39 \pm 0.15$ & $0.25 \pm 0.07$ & $0.36 \pm 0.08$ \\
\hline
\end{tabular}

picophytoplankton $<3 \mu \mathrm{m}$ predominates throughout the year. Surface chlorophyll $a$ concentrations in the SCS are higher than in the Kuroshio (Liu et al., 2002), which is attributed to a shallower nitracline in the SCS than in the Kuroshio.

The present study investigated the biochemical impacts of a cold-core eddy shed from the Kuroshio at the Luzon Strait in late spring when the SCS was relatively unproductive. Nutrient budgets, nitrate-based new production, primary production, and phytoplankton assemblages were compared between inside the eddy and its surrounding waters of the SCS and Kuroshio. Productivity in the eddy was also compared to the wintertime productivity of the SCS basin. Satellite images taken 15 days before and after the research cruise were compared to estimate the spatial extent of the eddy. This paper reports for the first time effects of a cold-core eddy on the biogeochemical budgets of the SCS.

\section{Materials and Methods}

Nine sampling stations (St. 2-10, Fig. 1) were occupied in the cruise SKII (R/V Fishery Researcher I, Taiwan Fisheries Research Institute) from April 21 through May 2, 2005. Station 5 at $20^{\circ} 15^{\prime}$ N, $120^{\circ} 31^{\prime}$ E was found to be in a cold-core eddy. Stations $2-4$ at the west side of $121^{\circ} \mathrm{E}$ were grouped as the SCS stations and St. 6-10 at the east side of $121^{\circ} \mathrm{E}$ were grouped as the Kuroshio stations. The SEATS (South East Asian Time-series Study) station at $18^{\circ} \mathrm{N}, 116^{\circ} \mathrm{E}$ in the SCS basin (Fig. 1) was treated as St. 1 in the present study to contrast the productivity dynamics between the eddy and the SCS. The data for St. 1 were compiled from a series of 14 cruises by R/V Ocean Researcher I from March 2000 through December 2005 and one cruise by R/V Fishery Researcher I. The 15 SEATS cruises included 5 in spring (CR 575, March 2000; CR 606, March 2001; CR 638, March 2002; FR33, March 2005 and CR 717, May 2005), 3 in summer (CR 588, July 2000; CR 722, July 2004 and CR 726, August 2004), 3 in autumn (CR 626, October 2001; CR 662, October 2002 and CR 736, November 2005), and 4 in winter (CR 673, January 2003; CR 708, February 2004; CR 743, January 2005 and CR 780, December 2005). FR 33 was conducted from March 28 through April 2, 2005, about one month earlier than the SKII cruise. The results of FR 33 at St. 1 were thus incorporated into SKII data analyses.

Several parameters were used to infer the state of physical, chemical or biological conditions during sam- 


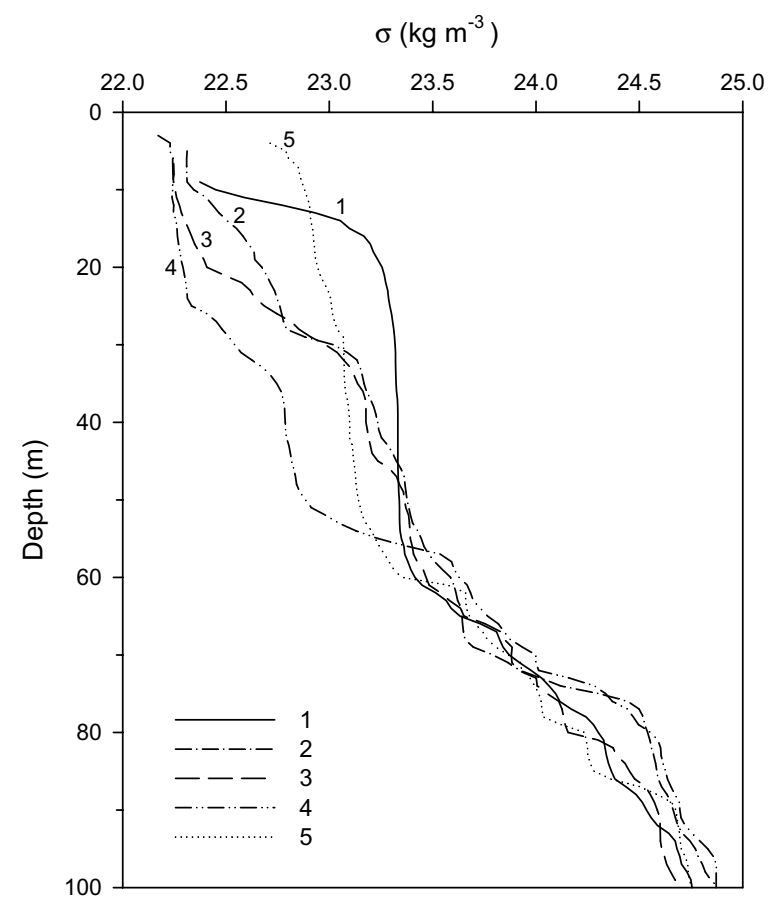

Fig. 3. Density profiles of the cold-core eddy station (St. 5) and the surrounding South China Sea (SCS) stations (St. 14) during April-May of 2005.

pling. Water samples for nutrient analyses and biochemical measurements were collected from six light penetration depths (LPD) corresponding to $100,46,38,13,5$ and $0.6 \%$ of surface irradiance. Chlorophyll $a$ concentrations were determined fluorometrically (Strickland and Parsons, 1972). Nitrate and nitrite concentrations $\left(\mathrm{NO}_{3}+\right.$ $\mathrm{NO}_{2}$ ) were measured by the chemiluminescent method (Garside, 1982) with a detection limit of 1-2 $\mathrm{nM}$. Nitracline depth was defined as the depth at which $\mathrm{NO}_{3}+\mathrm{NO}_{2}$ equals $0.1 \mu \mathrm{M}$ (Borgne et al., 2002). Soluble reactive phosphorus (SRP) was measured to nanomolar levels by the modified-MAGIC method with arsenate interference corrections (Thomson-Bulldis and Karl, 1998) and gave a detection limit of 2-3 nM within the range of $10-50 \mathrm{nM}$.

Euphotic depth (Zeu, m) was designated as the depth at which light intensity is $0.6 \%$ of surface irradiance. Mixed layer depth (MLD, $m$ ) was defined as the layer of water having a density $\left(\sigma_{\theta}\right)$ gradient less than 0.1 $\mathrm{kg} \mathrm{m}^{-3} \mathrm{~m}^{-1}$. The stratification index $\left(\mathrm{SI}, \mathrm{kg} \mathrm{m}^{-3}\right)$ was the average density difference between the surface and 100 $\mathrm{m}$ or the bottom, if the bottom depth was less than $100 \mathrm{~m}$.

Simulated in-situ shipboard experiments measuring phytoplankton uptake of $\mathrm{NaH}^{13} \mathrm{CO}_{3}$ were conducted to estimate primary production (Hama et al., 1983); whereas $\mathrm{Na}^{15} \mathrm{NO}_{3}$ uptake was measured to quantify the nitratebased new production (Dugdale and Wilkerson, 1986).

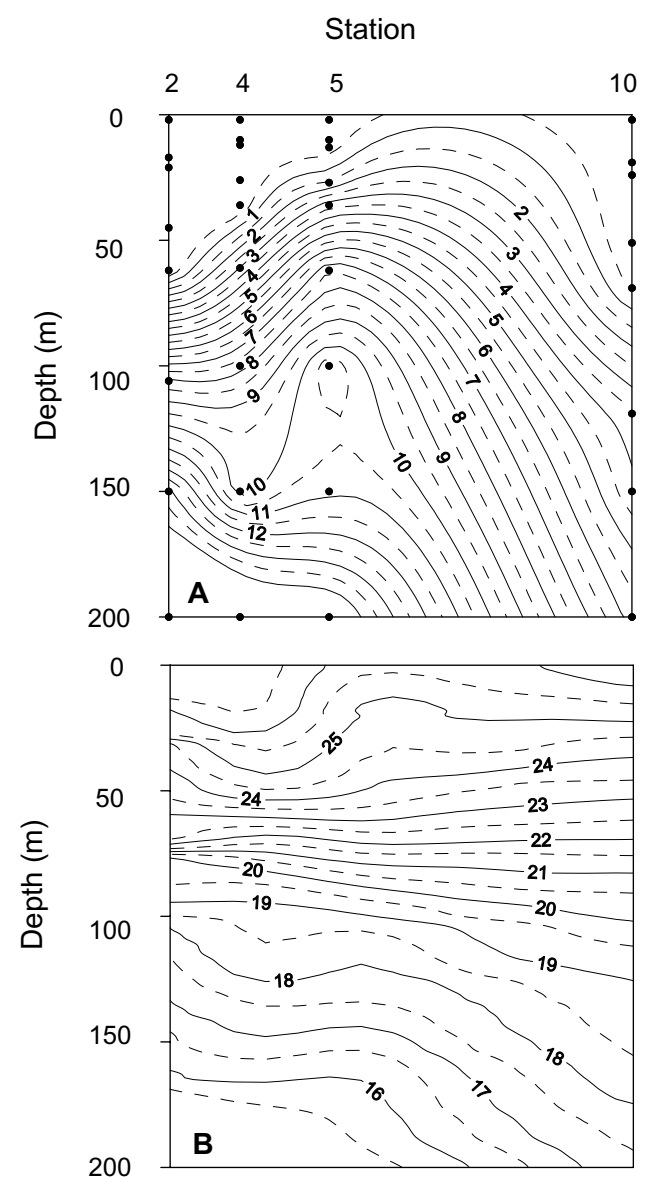

Fig. 4. Vertical profiles of (A) nitrate concentration $(\mu \mathrm{M})$ and (B) water temperature $\left({ }^{\circ} \mathrm{C}\right)$ for sampling stations along the $20^{\circ} \mathrm{N}$ transect in the South China Sea and Luzon Strait during April-May of 2005.

The methods were described in detail by Chen and Chen (2006). Two light bottles and one dark bottle were prepared for each of 6 LPD. Concentrations of particulate organic carbon and particulate nitrogen as well as the isotopic ratios of ${ }^{13} \mathrm{C} /{ }^{12} \mathrm{C}$ and ${ }^{15} \mathrm{~N} /{ }^{14} \mathrm{~N}$ were measured by a mass spectrometer (ANCA-MASS 20-20, Europa Scientific Ltd., Crewe, U.K.). When calculating nitrate-based new production, nitrogen was converted to carbon by assuming the Redfield ratio stoichiometry $(\mathrm{C}=\mathrm{N} \times 6.6$ by moles; Dugdale et al., 1989). Depth integrated production was calculated by trapezoidal integration of the entire euphotic zone (100-0.6\% surface irradiance) for the primary production (IPP) and new production (INP), and expressed as g C per $\mathrm{m}^{2}$. Production experiments were carried out at St. 2, 3, 5, 8, 9 and 10 during the SKII cruise and at St. 1 during all SEATS cruises.

To understand the phytoplankton community structure, seawater samples were filtered on board the ship on $10 \mu \mathrm{m}$ polycarbonate membrane filters (Whatman, 


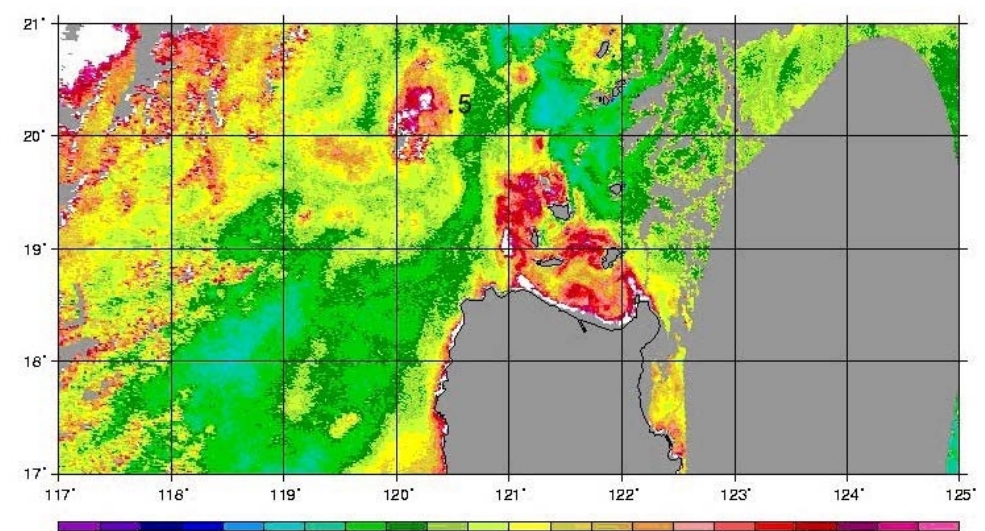

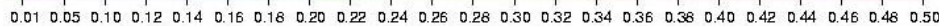
seawifs_20050429_HROC_L2 $1 \mathrm{Km} \mathrm{Chl-a}\left(\mathrm{mg}^{\prime} / \mathrm{m}^{3}\right)$

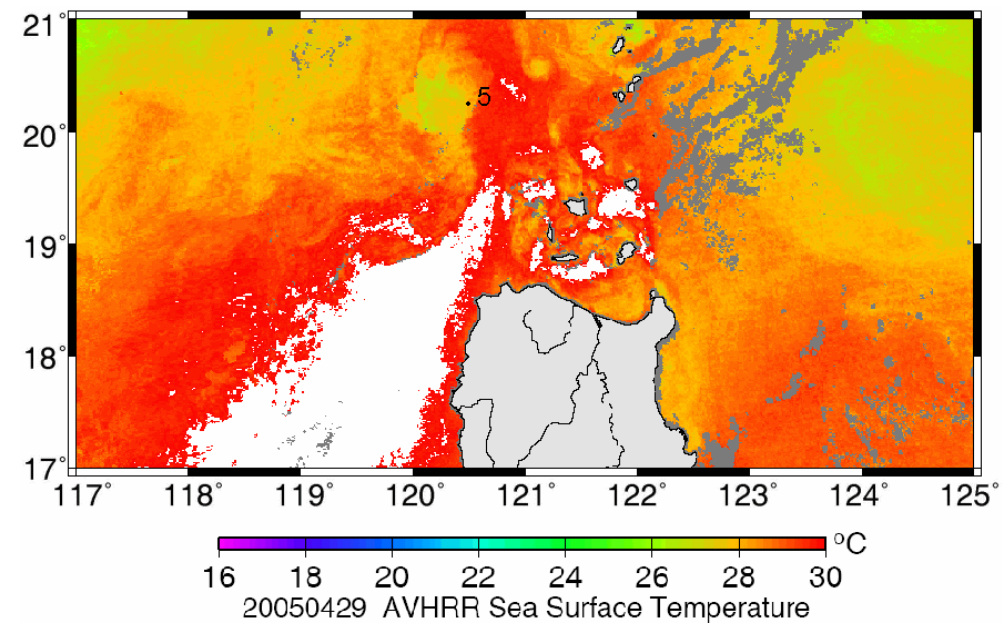

AVISO

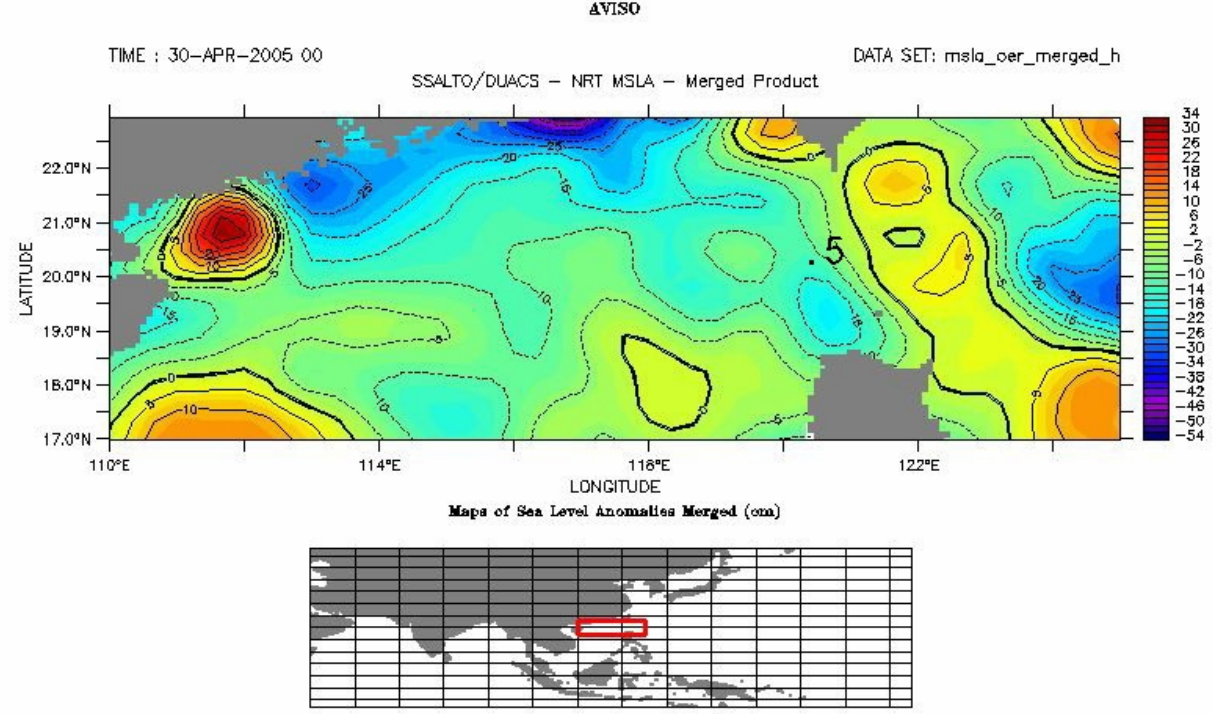

Fig. 5. Images taken on April 29, 2005 of SeaWiFS-derived chlorophyll $a$ concentration (top), AVHRR sea surface temperature (middle), and (TOPEX)/Poseidon and Jason-1 sea surface height anomaly (bottom) in the Luzon Strait, exhibiting the cold eddy feature. Station 5 was in the core of the eddy. 
Table 2. Abundance of pico-phytoplanktonic Prochlorococcus, Synechococcus and pico-eucaryotes in the surface water and water column (integrated from the surface to $200 \mathrm{~m}$ ) of the cold-core eddy station (St. 5) and the surrounding South China Sea (SCS) stations (St. 2-4) and Kuroshio stations (St. 6-10) during April-May of 2005.

\begin{tabular}{lrccr}
\hline Location & Station & Prochlorococcus & Synechococcus & Pico-eucaryotes \\
\hline Surface water $\left(\times 10^{6} 1^{-1}\right)$ & & & & \\
Eddy & 5 & 125.03 & 81.22 & 10.64 \\
SCS stations & 2 & 164.58 & 17.10 & 2.24 \\
& 3 & 163.98 & 16.52 & 1.98 \\
Kuroshio stations & 4 & 82.92 & 12.72 & 1.73 \\
& 6 & 30.83 & 3.87 & 0.88 \\
& 7 & 60.82 & 6.63 & 0.62 \\
Water column $\left(\times 10^{12} \mathrm{~m}^{-2}\right)$ & 8 & 204.63 & 5.33 & 1.39 \\
Eddy & 9 & 61.64 & 4.14 & 1.75 \\
SCS stations & & 33.95 & 4.50 & 1.17 \\
& 5 & & & \\
Kuroshio stations & 2 & 30.0 & 3.51 & 1.10 \\
& 3 & 24.3 & 2.36 & 0.45 \\
& 4 & 13.8 & 2.61 & 1.35 \\
& 6 & 27.1 & 2.76 & 0.76 \\
& 7 & 12.1 & 0.61 & 0.29 \\
& 8 & 34.0 & 0.52 & 0.24 \\
& 9 & 18.4 & 0.57 & 0.41 \\
& 10 & 11.3 & 0.50 & 0.21 \\
\end{tabular}

Brentford, U.K.) and were stored at $-4^{\circ} \mathrm{C}$ until later checking with a Zeiss Axioskop fluorescence microscope. Diatom, dinoflagellates, and filamentous blue-green algae Trichodesmium spp. and Richelia intracellularis were identified and counted in most of the SKII samples and some representative SEATS samples. Picophytoplankton in the SKII samples, including Prochlorococcus, Synechococcus and pico-eukaryotes, was enumerated by a LSR flow cytometer (Becton Dickinson, Franklin Lakes, NJ). Water samples for picophytoplankton studies were preserved with paraformaldehyde (final concentration $0.2 \%$ ), quickly frozen in liquid nitrogen, and stored at $-80^{\circ} \mathrm{C}$ until cytometric analysis (Vaulot et al., 1989).

We studied a series of satellite images taken on April 29, 2005, and 15 days before and after, when the cold eddy St. 5 was occupied. Chlorophyll- $a$ maps were from the $1 \mathrm{~km}$ resolution LAC (Local Area Coverage) data of the NASA's SeaWiFS (Sea-viewing Wide Field-of-view Sensor) ocean color satellite (O'Reilly et al., 1998). Sea surface temperature (SST) data were from the $1 \mathrm{~km}$ Advanced Very High Resolution Radiometer (AVHRR) of the US National Oceanic and Atmospheric Administration (NOAA) (Rao and Chen, 1996). Sea surface height anomaly (SSHA) data were obtained from the delayed mode product of the NASA Topography Experiment for Ocean Circulation (TOPEX)/Poseidon and Jason-1 missions (Fu et al., 1994).

Stepwise multiple regression analysis (Draper and
Smith, 1981) was used to examine the spatial and temporal relationships of nitrate-based new production, primary production, water temperature, Zeu, MLD, SI, $\left[\mathrm{NO}_{3}+\right.$ $\mathrm{NO}_{2}$ ], SRP, nitracline depth and chlorophyll $a$ concentration. PC-based StatView programs (SAS Institute Inc., Cary, NC) were used to conduct the statistical procedures.

\section{Results}

Water properties as indicated by $\theta / \mathrm{S}$ curves (Fig. 2) differed between the east (Kuroshio) side and the west (SCS) side of $121^{\circ} \mathrm{E}$. Those on the east side were similar to Kuroshio waters (Fig. 2A), while those on the west side showed mixed characteristics of Kuroshio and SCS waters in the upper water column and characteristics of SCS water in the lower part (Fig. 2B). While the SCS is generally less saline than the Kuroshio in the surface waters, salinity maxima and minima in the SCS are less distinctive than in the Kuroshio. The water column at St. 6 demonstrated Kuroshio water properties from the surface to about $290 \mathrm{~m}$, and SCS water properties below 290 $\mathrm{m}$ (Fig. 2A), indicating an eastward flow of the SCS intermediate water. With a salinity minimum similar to SCS water (Fig. 2B), St. 5 exhibited many extreme values in physical and biochemical indices measured during the SKII cruise (Table 1), including the lowest surface temperature $\left(25.8^{\circ} \mathrm{C}\right)$ and much less stratification than the surrounding SCS stations (Fig. 3). Depth contours of nitrate concentration (Fig. 4A) and temperature (Fig. 4B) 

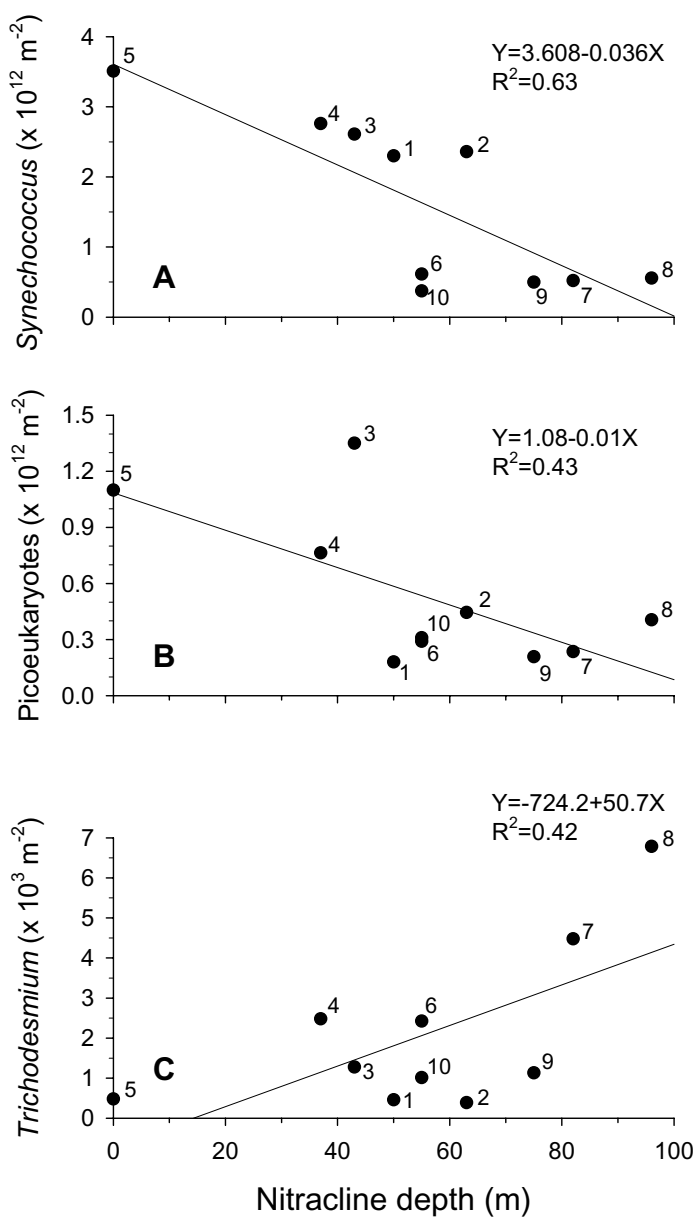

Fig. 6. Relationships between water column integrated biomass of (A) Synechococcus $\left(\times 10^{12} \mathrm{~m}^{-2}\right)$, (B) picoeukaryotes $\left(\times 10^{12} \mathrm{~m}^{-2}\right)$, and $(\mathrm{C})$ Trichodesmium $\left(\times 10^{3}\right.$ trichome $\left.\mathrm{m}^{-2}\right)$ and nitracline depth $(\mathrm{m})$ in the cold-core eddy station (St. 5) and its surrounding South China Sea (St. 2-4) and Kuroshio (St. 6-10) stations studied during April-May of 2005.

along the $20^{\circ} \mathrm{N}$ transect clearly featured a dome shape, typical of upwellings, near St. 5. Surface $\mathrm{NO}_{3}+\mathrm{NO}_{2}$ concentrations at St. 5 were almost 10 times higher than the surrounding SCS and Kuroshio waters (Table 1). Satellite images of sea surface temperatures and sea surface height anomalies (Fig. 5) showed a core of low surface temperatures, extending from $19^{\circ} 40^{\prime} \mathrm{N}$ to $20^{\circ} 40^{\prime} \mathrm{N}$ and from $119^{\circ} 45^{\prime} \mathrm{E}$ to $120^{\circ} 35^{\prime} \mathrm{E}$, with a diameter of about 85 $\mathrm{km}$. The SeaWiFS images of surface chlorophyll $a$ concentrations also showed an area of surface pigment enhancement coinciding with the low temperature core (Fig. 5). In the ground measurements, St. 5 had the highest surface chlorophyll $a$ concentrations among all stations (Table 1).

Station 5 also showed the highest primary produc-
Table 3. Abundance (cells $1^{-1}$ ) of pennate and centric diatoms in the surface water of the cold-core eddy station (St. 5) and the surrounding South China Sea (SCS) and Kuroshio stations during April-May of 2005*.

\begin{tabular}{lrrrrr}
\hline & Eddy & \multicolumn{2}{c}{ South China Sea } & Kuroshio \\
Genera & 5 & 1 & 3 & 4 & 8 \\
\hline Pennate diatoms & & & & & \\
$\quad$ Fragilaria & 51 & 1 & 1 & 109 & 8 \\
Navicula & 62 & 2 & 2 & 22 & 15 \\
Nitzschia & 448 & & & 157 & \\
Thalassionema & 783 & & & 38 & 17 \\
Thalassiothrix & 116 & & 1 & & 8 \\
Other pennates & 111 & 2 & 2 & 21 & 7 \\
Overall & 1571 & 5 & 6 & 347 & 55 \\
& & & & & \\
Centric diatoms & & & & & \\
Bacteriastrum & 241 & 12 & 9 & 76 & 4 \\
Chaetoceros & 727 & 46 & 39 & 298 & 43 \\
$\begin{array}{l}\text { Dactyliosolen } \\
\text { Hemiaulus }\end{array}$ & 148 & & 20 & & \\
Leptocylindrus & & 14 & 2 & 44 & 5 \\
Rhizosolenia & 65 & 3 & 19 & 95 & 14 \\
Other centrics & 85 & 2 & 4 & 32 & 7 \\
Overall & 1266 & 79 & 93 & 601 & 73 \\
$\quad$ Total diatoms & 2837 & 84 & 99 & 948 & 128 \\
\hline
\end{tabular}

*For comparison, average abundance of pennate diatoms at the SEATS station in the SCS basin was 90 cells $1^{-1}$ in summer and 980 cells $1^{-1}$ in winter; and average abundance of centric diatoms was 310 cells $1^{-1}$ in summer and 1340 cells $1^{-1}$ in winter (Chen, 2005).

tion and nitrate-based new production of all stations. IPP and INP of St. 5 were about 2-3 times those of the SCS stations (Table 1), and INP was 6 times the Kuroshio stations. Among all stations surveyed, INP was significantly positively correlated with surface $\mathrm{NO}_{3}+\mathrm{NO}_{2}$ concentration $(\mathrm{r}=0.79, \mathrm{p}<0.05)$ and surface chlorophyll $a$ concentration $(r=0.81, p<0.05)$, and negatively correlated with nitracline depth $(\mathrm{r}=-0.84, \mathrm{p}<0.05)$. Surface $\mathrm{NO}_{3}+$ $\mathrm{NO}_{2}$ concentration, surface chlorophyll $a$ concentration, and nitracline depth correlated with each other, with significant relationships between nitracline depth and $\mathrm{NO}_{3}+\mathrm{NO}_{2}(\mathrm{r}=-0.80, \mathrm{p}<0.05)$, and between $\mathrm{NO}_{3}+$ $\mathrm{NO}_{2}$ and chlorophyll $a(\mathrm{r}=0.94, \mathrm{p}<0.01)$. IPP also was significantly correlated with surface chlorophyll $a$ concentration $(r=0.83, p<0.05)$.

During the SKII survey, the northern SCS was more productive than the Kuroshio, although surface $\mathrm{NO}_{3}+$ $\mathrm{NO}_{2}$ abundances in the two regions were similar. Average INP at the SCS stations was twice that at the Kuroshio stations (Table 1); this might be attributable to the shal- 
Table 4. Integrated water column abundances of Trichodesmium spp. and Richelia intracellularis at the cold-core eddy station (St. 5) and the surrounding South China Sea and Kuroshio stations during April-May of 2005.

\begin{tabular}{lccc}
\hline Location & Station & $\begin{array}{c}\text { Trichodesmium } \mathrm{spp} . \\
\left(\text { trichome }, \times 10^{3} \mathrm{~m}^{-2}\right)\end{array}$ & $\begin{array}{c}\text { R. intracellularis } \\
\left(\text { trichome, } \times 10^{2} \mathrm{~m}^{-2}\right)\end{array}$ \\
\hline Eddy & 5 & & \\
& & 0.48 & 3.29 \\
South China Sea & & & \\
& 1 & 0.54 & 3.89 \\
& 2 & 0.39 & 3.22 \\
& 3 & 1.28 & 1.17 \\
& 4 & 2.48 & 2.25 \\
Kuroshio & & & \\
& & & 2.34 \\
& 6 & 2.42 & 3.45 \\
& 7 & 4.48 & 5.58 \\
& 8 & 6.79 & 4.26 \\
& 9 & 1.13 & 4.73 \\
\hline
\end{tabular}

Table 5. Comparisons of selected biochemical characteristics including surface water temperature, surface chlorophyll $a$ concentration (Chl), $\mathrm{NO}_{3}+\mathrm{NO}_{2}$ concentration, and stratification index of water column (SI), depth of mixed layer (MLD), as well as water column integrated primary production (IPP) and nitrate-based new production (INP) at the cold-core eddy station (St. 5) and at the SEATS (South East Asian Time-series Study) station (same as St. 1 in this study). The eddy station was investigated in late spring (April) of 2005; Seasonal means are presented for the SEATS station.

\begin{tabular}{lccccc}
\hline Variables & Eddy & \multicolumn{4}{c}{ SEATS station } \\
\cline { 3 - 6 } & station & Winter & Autumn & Spring & Summer \\
& $(n=1)^{*}$ & $(n=4)$ & $(n=3)$ & $(n=5)$ & $(n=3)$ \\
\hline Temperature $\left({ }^{\circ} \mathrm{C}\right)$ & 25.8 & 23.7 & 28.1 & 25.9 & 29.8 \\
Chl $\left(\mathrm{mg} \mathrm{m}^{-3}\right)$ & 0.40 & 0.29 & 0.12 & 0.13 & 0.09 \\
$\mathrm{NO}_{3}+\mathrm{NO}_{2}(\mathrm{nM})$ & 107 & 146 & 58 & 33 & 9 \\
$\mathrm{SI}\left(\mathrm{kg} \mathrm{m}^{-3}\right)$ & 2.53 & 1.07 & 3.07 & 2.30 & 3.70 \\
$\mathrm{MLD}\left(\mathrm{m}^{-3}\right.$ & 26 & 78 & 52 & 35 & 31 \\
$\mathrm{IPP}\left(\mathrm{g} \mathrm{C} \mathrm{m}^{-2} \mathrm{~d}^{-1}\right)$ & 1.09 & 0.55 & 0.40 & 0.31 & 0.25 \\
$\mathrm{INP}\left(\mathrm{g} \mathrm{C} \mathrm{m}^{-2} \mathrm{~d}^{-1}\right)$ & 0.67 & 0.19 & 0.07 & 0.07 & 0.06 \\
\hline
\end{tabular}

$*_{n}$ indicates number of cruise visits.

lower nitracline depth in the SCS than in the Kuroshio. Integrated $\mathrm{NO}_{3}+\mathrm{NO}_{2}$ abundance for the upper $100 \mathrm{~m}$ water column in the SCS was obviously higher than in the Kuroshio (Table 1). IPP, however, was similar in the SCS and the Kuroshio, which may be attributed to the deeper euphotic layer in the Kuroshio $(131 \mathrm{~m})$ than in the SCS $(96 \mathrm{~m})$. Nevertheless, surface PP in the SCS was still higher than in the Kuroshio (Table 1).

The phytoplankton assemblage of St. 5 was unique in many respects (Table 2). In terms of abundance in both surface water and water column, there were more Synechococcus and pico-eukaryotes in the SCS than in the Kuroshio. Synechococcus abundance at St. 5 was about
5 times that of the average value of the SCS stations, and was about 15 times that of the average value of the Kuroshio stations (Table 2). Similarly, pico-eukaryote abundance at St. 5 was 5 times the average of the SCS stations, which was higher than the Kuroshio average. By contrast, Prochlorococcus abundance in surface water of St. 5 was not enhanced over the SCS or the Kuroshio stations (Table 2). Synechococcus abundance at St. 5 was the highest of all stations. This superiority of abundance was more obvious in surface water than in the water column (Table 2). Synechococcus and pico-eukaryote abundances were closely related to nitrate availability. Integrated abundances of Synechococcus and pico-eukaryotes 


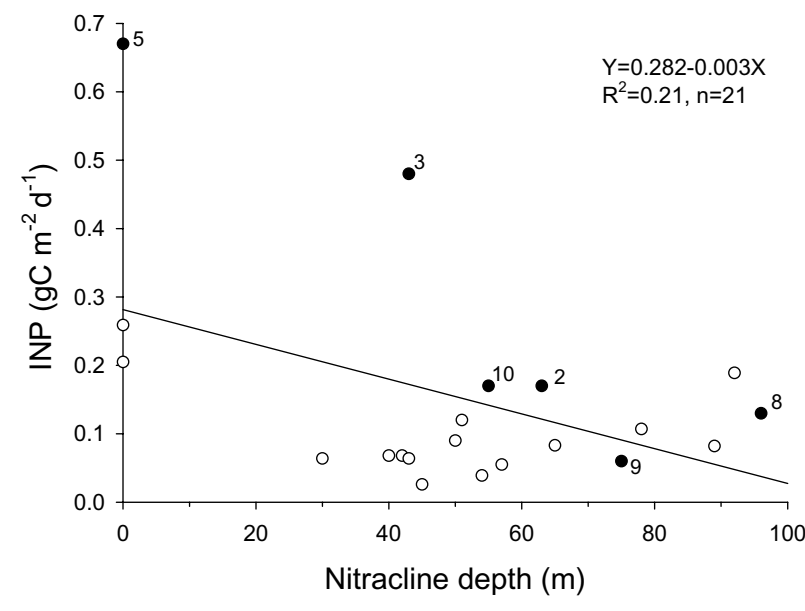

Fig. 7. Relationship between water column integrated nitratebased new production and nitracline depth for pooled multiseasonal data from the SEATS (South East Asian Time-series Study) station $(O)$ in the South China Sea and multistation data from the SKII cruise (, numbers indicate stations) in the Luzon Strait during April-May of 2005.

were both significantly negatively related to nitracline depth in meters (Figs. 6A and B). Their regression equations are: Synechococcus abundance $\left(\times 10^{12} \mathrm{~m}^{-2}\right)=3.608$ 0.036 Nitracline depth $\left(\mathrm{R}^{2}=0.63, \mathrm{p}<0.01\right)$, and Picoeukaryote abundance $\left(\times 10^{12} \mathrm{~m}^{-2}\right)=1.08-0.01$ Nitracline depth $\left(R^{2}=0.43, p<0.05\right)$.

Diatom abundances were greatly enhanced in the eddy relative to surrounding waters. Diatom abundances at St. 5 were 3-35 times those of all other stations in the SCS and Kuroshio (Table 3). Both pennate diatoms $\left(1.57 \times 10^{3} \mathrm{l}^{-1}\right)$ and centric diatoms $\left(1.27 \times 10^{3} \mathrm{l}^{-1}\right)$ flourished at the eddy station. Diatoms belonging to the genera Chaetoceros, Thalassionema, Nitzschia, and Bacteriastrum were more prevalent than other diatoms. In contrast to diatoms, abundances of diazotrophs were lower in the eddy than in surrounding waters (Table 4). Trichodesmium was much less abundant at St. 5 than in the SCS and the Kuroshio stations. Trichodesmium abundance was positively related to nitracline depth $(\mathrm{m})$, the regression equation being: Trichodesmium abundance $\left(\times 10^{3}\right.$ trichome $\left.\mathrm{m}^{-2}\right)=-724.2+50.7$ Nitracline depth $\left(\mathrm{R}^{2}=0.42, \mathrm{p}<0.05\right.$, Fig. $\left.6 \mathrm{C}\right)$. The abundances of diazotrophic Richelia intracellularis at St. 5 were similar to those in the SCS and the Kuroshio stations (Table 4).

Enhanced productivity in the eddy was compared with productivity of the SCS basin, inferred from the time series study in the SEATS station (South East Asian Timeseries Study) from 2000 through 2005. Seasonal fluctuations in water properties and productivity were obvious at SEATS (St. 1 in the present study). It was most pro- ductive, least stratified, and had the coldest surface water in winter (Table 5). Accordingly, surface water at St. 1 in winter had the seasonally highest $\mathrm{NO}_{3}+\mathrm{NO}_{2}$ and chlorophyll $a$ concentrations. On average, wintertime nitrate-based new production and primary production were about double those of other seasons.

Phytoplankton productivity was higher in the coldcore eddy than in the SCS basin. Surface chlorophyll $a$ concentration at St. 5 was higher than that of the wintertime average for St. 1 (Table 5). Nitrate-based new production and primary production at St. 5 were 3.5 and 2.0 times the wintertime average of St. 1, respectively. When INP from St. 1 and nine SKII stations were pooled for analyses, there was a significant, negative relationship $(p<0.05)$ between INP and nitracline depth (Fig. 7), indicating that nitrate availability drove INP dynamics regardless of seasonality or the existence of the cold-core eddy.

\section{Discussion}

Similar to other cyclonic eddies in the Northern Hemisphere, the cold-core eddy in the Luzon Strait showed enhanced nutrient abundances, chlorophyll $a$ concentrations, and nitrate-based new production. Phytoplankton assemblages in the eddy were also different from the surrounding waters. In the BATS study, elevated nutrient concentrations, chlorophyll $a$ concentrations, photosynthetic rates, and new production were found inside cyclonic eddies in the Sargasso Sea (McGillicuddy and Robinson, 1997; McGillicuddy et al., 1998, 1999; McNeil et al., 1999; Siegel et al., 1999; Sweeney et al., 2003). Enhanced nutrient abundances and phytoplankton productivity were also observed in the North Pacific subtropical gyre near Hawaii (Allen et al., 1996; Vaillancourt et al., 2003).

The responses of phytoplankton to the cold-core eddy were similar to those caused by wintertime mixing in the oligotrophic SCS when the prevailing Northeast Monsoon upwells subsurface nitrate, which supports phytoplankton growth that otherwise would be limited by deficient nitrogen (Chen et al., 2004; Chen, 2005). This nutrient mixing renders winter the most productive season (Chen, 2005). Enhanced nitrate-based new production was correctly reflected both in the eddy and in the wintertime mixing. Although the magnitude of production enhancement of the cold-core eddy in terms of space (surface area) was not as great as the wintertime mixing in the SCS basin, its magnitude in terms of biological responses was by no means less significant.

Within the eddy, abundant Synechococcus were found and their abundance was negatively related to nitracline depth, suggesting that nitrate availability might determine Synechococcus growth. Laboratory experiments have shown that Synechococcus isolates utilize nitrate (Moore 


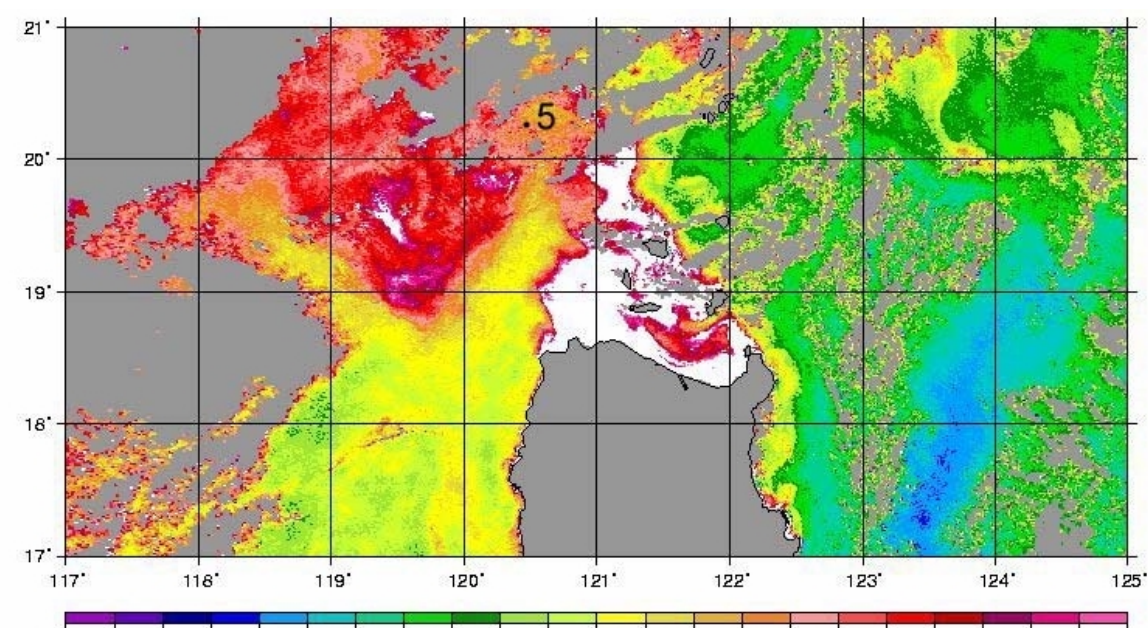

$\begin{array}{llllllllllllllllllllllll}0.01 & 0.05 & 0.10 & 0.12 & 0.14 & 0.16 & 0.18 & 0.20 & 0.22 & 0.24 & 0.26 & 0.28 & 0.30 & 0.32 & 0.34 & 0.36 & 0.38 & 0.40 & 0.42 & 0.44 & 0.46 & 0.48 & 0.50\end{array}$ seawifs_20050417_HROC_L2 1 Km Chl-a $\left(\mathrm{mg}^{\prime} \mathrm{m}^{3}\right)$

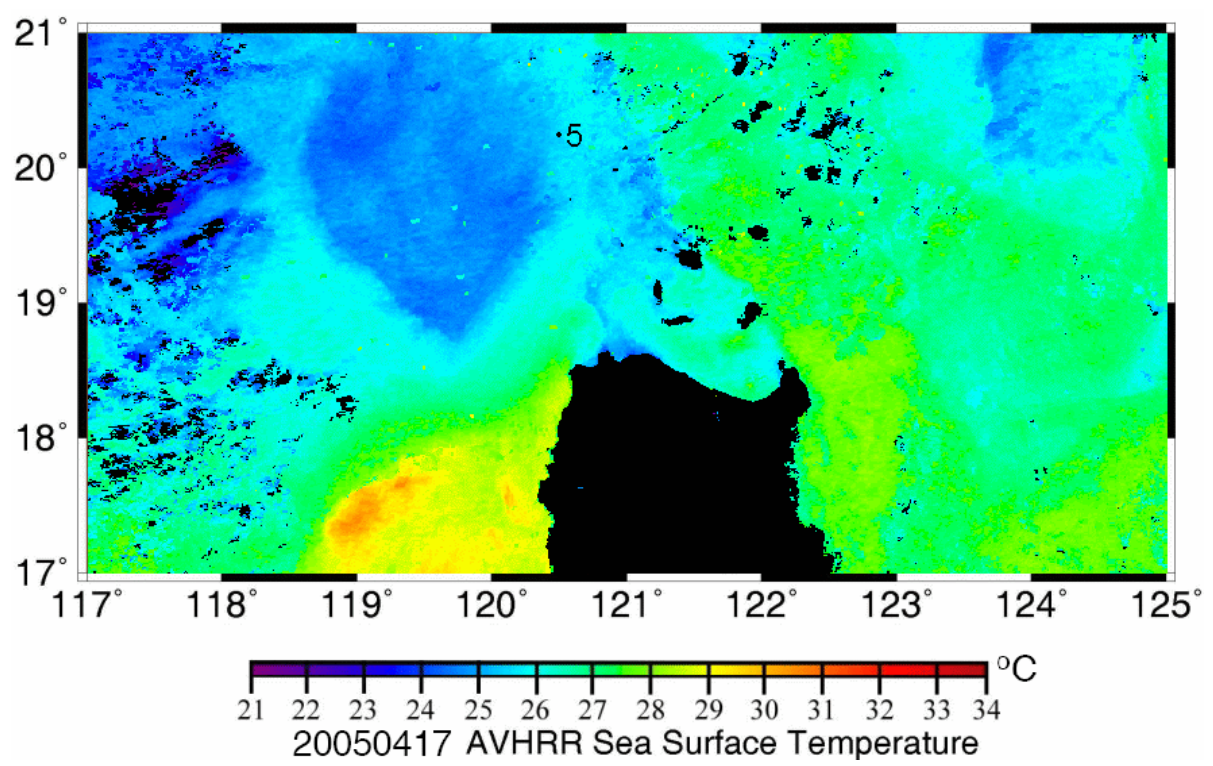

Fig. 8. Images taken on April 17, 2005 of SeaWiFS-derived chlorophyll $a$ concentration and AVHRR sea surface temperature in the Luzon Strait, showing the location of St. 5 and the extent of a cold-core eddy.

et al., 2002), and their growth rates correlate well with nitrate concentrations (Partensky et al., 1999). In field studies conducted in many oceanic regimes, nutrients, made available whenever a shoaling nitracline meets a deep mixed layer, support the thriving and blooming of Synechococcus. These enhancements have been reported in the Sargasso Sea (DuRand et al., 2001), Red Sea (Lindell and Post, 1995), and Mediterranean Sea (Bustillos-Guzman et al., 1995).

Unlike Synechococcus, Prochlorococcus was not enhanced from elevated nitrate abundance in the eddy. Although Prochlorococcus isolates grow well on $\mathrm{NH}_{4}^{+}$ and are capable of utilizing urea, they do not grow when nitrate is the nitrogen source (Moore et al., 2002). In contrast to the rapid response of Synechococcus to nutrient pulses (Glover et al., 1988), Prochlorococcus grow slowly (Liu et al., 1998). In general, Prochlorococcus can outcompete Synechococcus only in very oligotrophic oceans; therefore, Prochlorococcus accounts for a large fraction of phytoplankton biomass in the central oceanic gyres (Goericke and Welschmeyer, 1993; Letelier et al., 1993; Partensky et al., 1996). Up to $60 \%$ of phytoplankton biomass and $30 \%$ of particulate organic carbon in the central Pacific Ocean are Prochlorococcus (Campbell et al., 
1994). In the present study, Prochlorococcus, in terms of cells per liter (Table 2), were always more abundant than Synechococcus either inside or outside the eddy. The mechanism that controls the distribution of Prochlorococcus in the SCS is not clear.

Although Trichodesmium is an indicator species of the Kuroshio water mass, it is sparsely distributed in the SCS, even in the region adjoining the Kuroshio (Chen et al., 2003). The low abundance of Trichodesmium in the surface water of the eddy may explain part of the puzzle. Wu et al. (2003) speculated that the differential distribution is caused by deficiency in the SCS of bio-available iron, which is essential for nitrogen fixation and growth of Trichodesmium. Alternatively, Chen (2005) suggested that the higher nitrate availability in the SCS than in the Kuroshio, due to the shallower nitracline in the SCS, explained the scarcity of Trichodesmium in the SCS. The eddy station had the lowest Trichodesmium abundances of all stations. Surface water in the eddy had many characteristics unfavorable for growth of Trichodesmium, including a shallow nitracline, high nitrate abundance, and water divergence. Because the upper Kuroshio water, which carries Trichodesmium, flows westward into the SCS where multiple cold eddies could form (Chu et al., 1998), the unfavorable conditions might render the thriving of Trichodesmium unlikely.

Both diatoms and pico-phytoplankton prospered in the cold-core eddy. Simultaneous enhancement of both small cells, such as Synechococcus, and large cells, such as diatoms, in response to nutrient enrichment is not uncommon. Chen (2000) observed concerted thriving of large and small phytoplankton cells in upwellings in the southern East China Sea. In the SCS, large and small phytoplankton cells also flourish together in response to wintertime mixing (Chen, 2005).

The assemblage of the phytoplankton in St. 5 on April 29, 2005 probably represents a relatively late phase of nutrient enrichment from upwelling. SeaWiFS and AVHRR images taken as early as April 15 had already indicated the presence of the cold-core eddy. Images obtained on April 17 (Fig. 8) showed an enlargement of the eddy core, which had a diameter of about $250 \mathrm{~km}$. The eddy persisted at least until April 29 when the last SeaWiFS image available confirmed its presence.

Calculation of the Aging Index of Upwelling (AIU, Takahashi et al., 1986) reaffirmed that the eddy was in a late phase of nutrient enhancement. The index that is calculated as $\mathrm{AIU}=0.7[\mathrm{Chl}] /\left\{\left[\mathrm{NO}_{3}+\mathrm{NO}_{2}\right]+0.7[\mathrm{Chl}]\right\}$ is based on the relative percentages of biologically important elements in inorganic form $\left(\mathrm{NO}_{3}+\mathrm{NO}_{2}\right.$ in the present study) and organic form (Chlorophyll $a$ ). AIU value varies between 0 and 1 ; an AIU $<0.5$ indicates young upwelling, whereas an AIU > 0.5 indicates old upwelling (Takahashi et al., 1986). With a chlorophyll $a$ concentra- tion of $0.40 \mu \mathrm{g}^{-1}$ and a $\mathrm{NO}_{3}+\mathrm{NO}_{2}$ concentration of $0.107 \mu \mathrm{M}$, the AIU in the present eddy is 0.72 , indicating a relatively old phase of upwelling. This, together with the indications from satellite images, suggests that the different phytoplankton assemblage we observed in the eddy was the cumulative result of a process lasting at least 15 days. Contrasting abundances of some phytoplankton inside and outside the eddy might result from successive changes during that period. Primary production and new production rates reported at St. 5 were only a snapshot observed during the development of the upwelling. The rates could be changed as the upwelling ages, corresponding to the accompanying changes of nitrate concentration and phytoplankton biomass.

\section{Acknowledgements}

We thank Y. H. Lin, H. J. Yang, H. H. Tuo and G. A. Han for their assistance in sample collection and analyses and the captains and crews of R/V Fishery Researcher I and Ocean Researcher I for their cooperation during cruises. This research was supported in part by grants from the National Science Council (NSC 93-2611-M110-003, 94-2611-M110-009 and 95-2611-M110-002). This paper represents Contribution number 6 of Asia-Pacific Ocean Research Center, National Sun Yat-sen University.

\section{References}

Allen, C. B., J. Kanda and E. A. Laws (1996): New production and photosynthetic rates within and outside a cyclonic mesoscale eddy in the North Pacific subtropical gyre. DeepSea Res. I, 43, 917-936.

Borgne, R. L., R. T. Barber, T. Delcroix, H. Y. Inoue, D. J. Mackey and M. Rodier (2002): Pacific warm pool and divergence: temporal and zonal variations on the equator and their effects on the biological pump. Deep-Sea Res. II, 49, 2471-2512.

Bustillos-Guzman, J., H. Claustre and J. C. Marty (1995): Specific phytoplankton signatures and their relationship to hydrographic conditions in the coastal northwestern Mediterranean Sea. Mar. Ecol. Prog. Ser., 124, 247-258.

Campbell, L., H. A. Nolla and D. Vaulot (1994): The importance of Prochlorococcus to community structure in the central North Pacific Ocean. Limnol. Oceanogr., 39, 954961.

Chen, C. T. A. and M. H. Huang (1996): A mid-depth front separating the South China Sea water and the Philippine Sea water. J. Oceanogr., 52, 17-25.

Chen, Y. L. L. (2000): Comparisons of primary productivity and phytoplankton size structure in the marginal regions of southern East China Sea. Cont. Shelf Res., 20, 437-458.

Chen, Y. L. L. (2005): Spatial and seasonal variations of nitrate-based new production and primary production in the South China Sea. Deep-Sea Res. I, 52, 319-340.

Chen, Y. L. L. and H. Y. Chen (2006): Seasonal dynamics of primary and new production in the northern South China Sea: the significance of river discharge and nutrient advection. Deep-Sea Res. I, 53, 971-986. 
Chen, Y. L. L., H. Y. Chen and Y. H. Lin (2003): Distribution and downward flux of Trichodesmium in the South China Sea as influenced by the transport from the Kuroshio Current. Mar. Ecol. Prog. Ser., 259, 47-57.

Chen, Y. L. L., H. Y. Chen, D. M. Karl and M. Takahashi (2004): Nitrogen modulates phytoplankton growth in spring in the South China Sea. Cont. Shelf Res., 24, 527-541.

Chern, C. S. and J. Wang (2003): Numerical study of the upper-layer circulation in the South China Sea. J. Oceanogr., 59, 11-24.

Chu, P. C. and C. Fan (2001): Low salinity, cool-core cyclonic eddy detected northwest of Luzon during the South China Sea Monsoon Experiment (SCSMEX) in July 1998. J. Oceanogr., 57, 549-563.

Chu, P. C., C. Fan, C. J. Lozano and J. Kerling (1998): An airborne expandable bathythermograph (AXBT) survey of the South China Sea, May 1995. J. Geophys. Res., 103, $21637-$ 21652.

Draper, N. R. and H. Smith (1981): Applied Regression Analysis. Wiley, New York, 709 pp.

Dugdale, R. C. and F. P. Wilkerson (1986): The use of ${ }^{15} \mathrm{~N}$ to measure nitrogen uptake in eutrophic oceans: experimental considerations. Limnol. Oceanogr., 31, 673-689.

Dugdale, R. C., A. Morel, A. Bricaud and F. P. Wilkerson (1989): Modeling new production in upwelling centers: a case study of modeling new production from remotely sensed temperature and color. J. Geophys. Res., 94, 18119-18132.

DuRand, M. D., R. J. Olson and S. W. Chisholm (2001): Phytoplankton population dynamics at the Bermuda Atlantic time-series station in the Sargasso Sea. Deep-Sea Res. II, 48, 1983-2003.

Fu, L. L., E. J. Christensen, C. A. Yamarone, M. Lefebvre, Y. Menard, M. Dorrer and P. Escudier (1994): TOPEX/ POSEIDON mission overview. J. Geophys. Res., 99, 24369 24381.

Garside, C. (1982): A chemiluminescent technique for the determination of nanomolar concentrations of nitrate and nitrite in seawater. Mar. Chem., 11, 159-167.

Glover, H. E., B. B. Prézelin, L. Campbell, M. Wyman and C. Garside (1988): A nitrate-dependent Synechococcus bloom in surface Sargasso Sea water. Nature, 331, 161-163.

Goericke, R. and N. A. Welschmeyer (1993): The marine prochlorophyte Prochlorococcus contributes significantly to phytoplankton biomass and primary production in the Sargasso Sea. Deep-Sea Res., 40, 2283-2294.

Hama, T., T. Miyazaki, Y. Ogawa, T. Iwakumi, M. Takahashi, A. Otsuki and S. Ichimura (1983): Measurement of photosynthetic production of a marine phytoplankton population using a stable ${ }^{13} \mathrm{C}$ isotope. Mar. Biol., 73, 31-36.

Jia, Y. and Q. Liu (2004): Eddy shedding from the Kuroshio bend at Luzon Strait. J. Oceanogr., 60, 1063-1069.

Jia, Y., Q. Liu and W. Liu (2005): Primary study of the mechanism of eddy shedding from the Kuroshio bend in Luzon Strait. J. Oceanogr., 61, 1017-1027.

Letelier, R. M., R. R. Bidigare, D. V. Hebel, M. Ondrusek, C. D. Winn and D. M. Karl (1993): Temporal variability of phytoplankton community structure based on pigment analysis. Limnol. Oceanogr., 38, 1420-1437.

Li, L., W. D. Nowlin, Jr. and J. Su (1998): Anticyclonic rings from the Kuroshio in the South China Sea. Deep-Sea Res. I, 45, 1469-1482.

Li, Y., L. Li, M. Lin and W. Cai (2002): Observation of mesoscale eddy fields in the sea south west of Taiwan by TOPEX/POSEIDON altimeter data. Acta Oceanol. Sin., 24, 163-170 (in Chinese with English abstract).

Lindell, D. and A. E. Post (1995): Ultraphytoplankton succession is triggered by deep winter mixing in the Gulf of Aqaba (Eilat), Red Sea. Limnol. Oceanogr., 40, 1130-1141.

Liu, H., L. Campbell, M. R. Landry, H. A. Nolla, S. L. Brown and J. Constantinou (1998): Prochlorococcus and Synechococcus growth rates and contributions to production in the Arabian Sea during the 1995 Southwest and Northeast Monsoons. Deep-Sea Res. II, 45, 2327-2352.

Liu, K. K., S. Y. Chao, P. T. Shaw, G. C. Gong, C. C. Chen and T. Y. Tang (2002): Monsoon-forced chlorophyll distribution and primary production in the South China Sea: observations and a numerical study. Deep-Sea Res. I, 49, 13871412.

McGillicuddy, D. and A. R. Robinson (1997): Eddy induced nutrient supply and new production in the Sargasso Sea. Deep-Sea Res. I, 44, 1427-1449.

McGillicuddy, D., A. R. Robinson, D. A. Siegel, H. W. Jannasch, R. Johnson, T. D. Dickey, J. McNeil, A. F. Michaels and A. H. Knap (1998): Influence of mesoscale eddies on new production in the Sargasso Sea. Nature, 394, 263-265.

McGillicuddy, D., R. Johnson, D. A. Siegel, A. F. Michaels, N. R. Bates and A. H. Knap (1999): Mesoscale variations of biogeochemical properties in the Sargasso Sea. J. Geophys. Res., 104, 13381-13394.

McGillicuddy, D., L. A. Anderson, S. C. Doney and M. E. Maltrud (2003): Eddy-driven sources and sinks of nutrients in the upper ocean: results from a $0.1^{\circ}$ resolution model of the North Atlantic. Global Biogeochem. Cycles, 17(2), 1035, doi:10.1029/2002GB001987.

McNeil, J., H. W. Jannasch, T. D. Dickey, D. J. McGillicuddy, M. Brzezinski and C. M. Sakamoto (1999): New chemical bio-optical and physical observations of upper ocean response to the passage of a mesoscale eddy. J. Geophys. Res., 104, 15537-15548.

Metzger, E. J. and H. E. Hurlburt (1996): Coupled dynamics of the South China Sea, the Sulu Sea and the Pacific Ocean. $J$. Geophys. Res., 101, 12331-12352.

Metzger, E. J. and H. E. Hurlburt (2001): The nondeterministic nature of Kuroshio penetration and eddy shedding in the South China Sea. J. Phys. Oceanogr., 31, 1712-1732.

Moore, L. R., A. F. Post, G. Rocap and S. W. Chisholm (2002): Utilization of different nitrogen sources by the marine cyanobacteria Prochlorococcus and Synechococcus. Limnol. Oceanogr., 47, 989-996.

O'Reilly, J. E., S. Maritorena, B. G. Mitchell, D. A. Siegel, K. L. Carder, S. A. Garver, M. Kahru and C. McClain (1998): Ocean color chlorophyll algorithms for SeaWiFS. $J$. Geophys. Res., 103(C11), 24937-24953.

Partensky, F., J. Blanchot, F. Lantoine, J. Neveux and D. Marie (1996): Vertical structure of picophytoplankton at different trophic sites of the tropical northeastern Atlantic Ocean. Deep-Sea Res., 43, 1191-1213.

Partensky, F., J. Blanchot and D. Vaulot (1999): Differential 
distribution and ecology of Prochlorococcus and Synechococcus in oceanic waters: A review. p. 457-475. In Marine Cyanobacteria, ed. by L. Charpy and A. W. D. Larkum, Bulletin de Institut Oceanographique.

Rao, C. R. N. and J. Chen (1996): Post launch calibration of the visible and near-infrared channels of the Advanced Very High Resolution Radiometer on the NOAA-14 spacecraft. Intl. J. Remote Sens., 17, 2743-2747.

Siegel, D. A., D. J. McGillicuddy, Jr. and E. A. Fields (1999): Mesoscale eddies, satellite altimetry, and new production in the Sargasso Sea. J. Geophys. Res., 104(C6), 1335913379.

Strickland, J. D. H. and T. R. Parsons (1972): A practical handbook of seawater analysis. Bull. Fish. Res. Bd. Canada, 167, $1-310$.

Sweeney, E., D. McGillicuddy and K. Buesseler (2003): Biogeochemical impacts due to mesoscale eddy activity in the Sargasso Sea as measured at the Bermuda Atlantic Timeseries (BATS) site. Deep-Sea Res. II, 50, 3017-3039.

Takahashi, M., J. Ishizaka, T. Ishimaru, L. P. Atkinson, T. N. Lee, Y. Yamaguchi, Y. Fujita and S. Ichimura (1986): Temporal change in nutrient concentrations and phytoplankton biomass in short time scale local upwelling around the Izu Peninsula, Japan. J. Plankton Res., 8, 1039-1049.

Thomson-Bulldis, A. and D. Karl (1998): Application of a novel method for phosphorus determinations in the oligotrophic North Pacific Ocean. Limnol. Oceanogr., 43, 1565-1577.

Vaillancourt, R. D., J. Marra, M. P. Seki, M. L. Parsons and R. R. Bidigare (2003): Impact of a cyclonic eddy on phytoplankton community structure and photosynthetic competency in the subtropical North Pacific Ocean. DeepSea Res. I, 50, 829-847.

Vaulot, D., C. Courties and F. Partensky (1989): A simple method to preserve oceanic phytoplankton for flow cytometric analyses. Cytom., 10, 629-635.

Wu, C. R., P. T. Shaw and S. Y. Chao (1999): Assimilating altimeter data into a South China Sea model. J. Geophys. Res., 104(C12), 29987-30005.

Wu, J., S. W. Chung, L. S. Wen, K. K. Liu, Y. L. Lee Chen, H. Y. Chen and D. M. Karl (2003): Dissolved inorganic phosphorus, dissolved iron, and Trichodesmium in the oligotrophic South China Sea. Global Biogeochem. Cycles, 17(1), 1008, doi:10.1029/2002GB001924. 